\title{
Regenerating Places outside the Metropolis. A Reading of Three Global Art-Related Processes and Development Trajectories
}

\author{
Ludovico Centis *(D) and Ezio Micelli (D) \\ Department of Architecture and Arts, Università Iuav di Venezia, Santa Croce 191, 30135 Venezia, Italy; \\ micelli@iuav.it \\ * Correspondence: lcentis@iuav.it
}

check for

updates

Citation: Centis, L.; Micelli, E. Regenerating Places outside the Metropolis. A Reading of Three Global Art-Related Processes and Development Trajectories. Sustainability 2021, 13, 12359. https://doi.org/10.3390/ su132212359

\section{Academic Editors:}

Federico Dell'Anna and Marta Dell'Ovo

Received: 24 September 2021 Accepted: 4 November 2021 Published: 9 November 2021

Publisher's Note: MDPI stays neutral with regard to jurisdictional claims in published maps and institutional affiliations.

Copyright: (c) 2021 by the authors. Licensee MDPI, Basel, Switzerland. This article is an open access article distributed under the terms and conditions of the Creative Commons Attribution (CC BY) license (https:// creativecommons.org/licenses/by/ $4.0 /)$.

\begin{abstract}
The aim of the paper is to reflect on the intersection of two relevant phenomena that unfolded in recent decades in all the most industrialized countries and economies-from the United States to Europe and Japan - as the shrinkage of vast urban and rural areas and the increasing role of culture as a driver for economic growth and social development. The attention is focused on the role of art as one of the main engines of territorial regeneration. Three case studies-Verzegnis in Italy, the Seto Islands in Japan, Marfa in the United States—have been selected to open a reflection on the relation between culture, art and regeneration on a global scale. To measure these effects, the research intertwined field explorations, access to primary and secondary texts, an original mapping of the sites and a series of targeted interviews through an extensive questionnaire. The research addresses the role played by art and culture both in the reuse of abandoned buildings and spaces and in the activation, involvement and self-empowerment of the inhabitants. The aim is not the definition of an immediately generalizable model but to reach the first synthesis, identifying general characters and opening future research paths that engage with the theoretical and practical implementation of politics related to heritage, culture and innovative regeneration processes.
\end{abstract}

Keywords: art-related regeneration; shrinkage; peripheral territories

\section{Introduction}

At the turn of the millennium, culture and art, in particular, assumed an unprecedented role and global significance, to the point that it became a primary means for addressing a wide range of political, economic and social issues [1]. Philipp Oswalt, in the introduction to the second volume of the Shrinking Cities publication titled "Interventions", stated with a tone between humor and bitterness that "When no one knows what to do, they invite artists" [2] (p. 13).

Following this line of reasoning, the aim of this paper is to reflect on the intersection of two relevant phenomena that unfolded in recent decades in all the most industrialized countries and economies, from the United States to Europe and Japan. The first is the shrinkage of vast urban and rural areas with recurring ingredients, such as demographic degrowth, the collapse of traditional economic models and the peripheral geographic location of the regions subject to this phenomenon. The second is the increasing belief or myth, as certain scholars suggest [3], in the role of culture as a driver for urban economic growth and social development in a global rush in which cities seek to strengthen their competitive position, regenerate their urban fabric and diversify their economy. Since the beginning of the century institutions and organizations, such as the Organisation for Economic Co-operation (OECD), and development increasingly recognized the employment of cultural resources as a multiplier for regeneration processes at the local and regional scale. In particular, the OECD highlighted the key role of cultural resources for social integration, 
the reorganization of the territory and the development of sustainable business models [4] (p. 23).

The objective of this paper is then to investigate case studies where the possible intersection, namely, the regeneration processes, on the cultural basis of peripheral shrinking territories of these two phenomena can be recognized.

Culture-led regeneration processes include various types of interventions, from cultural production to cultural consumption [5]. The research narrows down this vast field and questions, in particular, the role of art as one of the main engines of territorial regeneration and new development trajectories in peripheral areas in the face of global geographical polarization and growing inequality. Borrowing from Roberts and Sykes definition of urban regeneration [6] (p. 17), territorial regeneration can be defined as "a comprehensive and integrated vision and action which leads to the resolution of problems and which seeks to bring about a lasting improvement in the economic, physical, social and environmental condition of a territory that has been subject to change". It is relevant to underline that this paper considered the regeneration processes initiated or sustained both by private and public actors, while other scholars narrow down the field of regeneration as an "area based intervention which is public sector initiated, funded, supported, or inspired, aimed at producing significant sustainable improvements in the condition of local people, communities and places suffering from aspects of deprivation, often multiple in nature" [7] (p. 9).

Three case studies have been selected to open a reflection on the relation between culture, art and regeneration on a global scale. The objective is to go beyond a simple verification of the possible improvement of the economic indicators generated by the artistic programs in these contexts, verifying the effects on the cultural and social structure of these communities. The research addresses the role played by art and culture both in the reuse of abandoned buildings and spaces and in the activation, involvement and self-empowerment of the inhabitants. The aim is not the definition of an immediately generalizable model but to reach a first synthesis, identifying general characters and opening future research paths that engage with the theoretical and practical implementation of politics related to heritage, culture and innovative regeneration processes.

\section{Framework}

In a seminal text, Miles and Paddison [8] underlined the difficulty implied in the attempt to measure the actual role of culture in the processes of urban growth and competition between cities, posing questions that are still timely: "do we really understand the complex nature of the impact of cultural investment on our cities and how far are such decisions based on an informed analysis of how investment might change a city? More pointedly perhaps, what do such developments actually mean in terms of the lives of those people who live in that city? In short, to what extent is culture-led regeneration more about rhetoric than it is about reality?" [8] (p. 834).

From innovative studies in the 1990s [9] that resulted in a landmark publication as The Creative City: A Toolkit for Urban Innovators [10] stemmed a multitude of research and texts [11,12] that investigated the potential of culture as a sparkle for urban and territorial regeneration processes, often emphasizing its positive aspects. Following this hype, an increasing number of cities, regions and even small towns placed their hopes for a resurgence in culture-led development and, in more general terms, in social innovation that could be defined as the application of innovative ideas in a product, process or organizational methods that generate an impact and modify in a stable and positive way the level of well-being of a society or part of it through the creation of added value [13] as governance tools [14]. The same hype often brought uncritically intended creativity as a synonym of culture and to "import" in smaller cities models developed in metropolitan contexts that have hardly any success if repeated in the same format $[15,16]$.

Experience and studies have revealed that even when the effort to pursue culture-led development resulted successful in economic terms, a number of undesired side-effects often flourished, from benefiting only a limited group of wealthy and highly educated 
people to the activation of larger social exclusion and marginalization processes favorable only to specific high-income and educated social segments $[17,18]$. If on one side the effectiveness of culture-led regeneration processes has been thoroughly investigated by scholars as Sacco [19], in more recent years other scholars, such as Boltanski and Esquerre [20], raised further challenging and critical questions about the role of cultural artifacts, of art and artworks in relation to the growing inequalities of contemporary capitalist societies.

The shrinkage of entire regions and cities has indeed reached a global relevance, affecting contexts, as the case studies in the United States, United Kingdom, Germany, Russia and Japan considered in the research Shrinking Cities [21,22] testify. The shrinking phenomenon affected a multitude of areas with diverse geographical, cultural and economic backgrounds and inspired a set of public policies to address it, as the Shrink Smart program promoted by the European Union between 2009 and 2012 [23]. As further proof of the global relevance of this phenomenon, several key studies spanning from the early 1990s to our days could be mentioned, ranging from the United States to Japan. Notions as life cycle, obsolescence and waste are crucial in a milestone text as Kevin Lynch's Wasting Away [24] as well as at the core of more recent national and international research $[25,26]$. Since the early 2000s, European researchers produced significant contributions related to very diverse territories in morphological terms, from the Swiss Brachen, the most impervious alpine areas of the country [27], to the España vacía [28], the vast and sparsely populated region of Spain originating around Madrid and extending to regions as the Extremadura. Several anthologies tried to periodically map the evolution of spatial shrinkage on a global scale, focusing especially on cities $[29,30]$, and reports produced by management consulting corporations constantly remind of the challenge brought by demographic degrowth [31]. Following a different approach, scholars and research groups focused their attention on regionally circumscribed dynamics. This is the case of Dislivelli, based in Turin, who focused their work [32,33] on peripheral areas, such as the Piedmont Alps, or Kayoko Ota, that addressed projects and research developed by leading Japanese architects and offices as Toyo Ito, SANAA and Atelier Bow-Wow in remote islands and villages of the country $[34,35]$. Even if they are morphologically different, ranging from steep mountain valleys to vast flatlands, and they are located in different continents, all of these regions share certain qualities that make them peripheral: they are scarcely populated and are cut out and far away from by high speed and high-capacity systems of transportation, so that reaching them from large metropolitan areas often requires a considerable effort in temporal and economic terms.

Ota's research in particular underlines a recent shift of paradigm, with leading architects and intellectuals as Toyo Ito that explain why and how the renewed interest towards peripheral contexts is not going to be a temporary fashion. Ito shows an understanding of how remote sites can provide the conditions to develop more effectively and with a greater chance of success innovative projects, both in programmatic and spatial terms [34].

While culture-led regeneration in the past two decades has mainly been recognized or investigated by scholars in urban or metropolitan contexts [36,37], other studies expand the gaze engaging with wider and heterogenous territories such as the ones of the cityregions [38]. Architects and research agencies, such as Rem Koolhaas and AMO [39], went even further, suggesting in the exhibition and related catalogue "Countryside, The Future" for the Guggenheim Museum in New York City that the peripheral regions are today, and in the coming years, the place where innovative ideas and experiences are tested, not just in the field of art, architecture and urbanism, but also in agronomy, biotech and other cutting-edge sectors.

Shrinking is undeniably an outcome of demographic and economic degrowth, as several case studies in Japan testify [40]. Yet, its consequences reach also other dimensions, deeply modifying the social and cultural structure of entire districts, cities and regions. Therefore, shrinking should not be barely treated as a short-term problem to be solved through economic measures, and it is legitimate to consider alternative ways as art-related projects and programs that could play a key role in territorial regeneration. These pro- 
grams often respond to a growing trend in the most industrialized countries, where a transition is in course touching multiple dimensions [41]; programs and territorial policies address pressing issues, such as reducing economic, social and cultural inequalities and accomplishing the ecological transition [42].

Two main opposed risks are at stake when assigning art, a strategic role in processes of territorial regeneration: the first is to generate a feeling of rejection in a local community that is often despondent if not frustrated when importing alien concepts and approaches [2] (p. 424); the second is to fail to break the status quo, reproducing existing dynamics that obstruct the desired change. In order to prevent this second scenario Fabrizio Barca, former Italian minister and promoter of the Strategia Aree Interne, incentivized a programmatical "destabilization of traditional orders" [43] as a tool to break with habits that never brought successful results.

While artists, administrators and stakeholders should be aware of these risks, culture still represents a key community tool for reorganization processes in the face of the shrinkage phenomenon [44].

\section{Methodology}

There is still a great deal of debate about the role of culture as a driver for urban and territorial economic growth. This research aims at adding a new chapter in this debate by applying a double narrowing of the field of study in order to possibly obtain more objective and solid results.

First, the case studies have been selected addressing a specific aspect of cultural production-that is, art. Second, the choice is to focus on settlements and communities limited in size and located in peripheral areas, overcoming, or at least largely reducing, the challenges that large cities or densely inhabited territories pose when attempting to measure objectively the weight of culture-related policies as a tool to boost urban and economic growth. The research, therefore, aims also at measuring to which degree culture-driven-or more precisely art-driven policies - can produce any difference in peripheral areas and foster positive change in an evolving global condition where "geographical polarization within countries and cities will become more pronounced, and growth and shrinkage will coexist with climbing inequality. In the future, these inequities will increasingly be found more within countries than between them" [22] (p. 6). If this trend dates to the end of the 20th century, studies of scholars as Rodríguez-Pose [45] who has recently addressed the growing discontent in declining areas, confirm how this is still relevant and is likely to exacerbate in the coming years.

Lastly, in order to investigate and compare qualitative differences, a set of research tools [46] (p. 65) is planned by crossing explorations on the field, a series of targeted interviews and access to primary and secondary texts. Learning from experience in the field has resulted fundamental, both in the form of visits to the sites and in reporting the impressions of privileged actors in the three different case studies. To effectively report these impressions a clear choice has been made to produce "vertical", in-depth face-to-face interviews rather than opting for an "horizontal" model with the collection and interpretation of big data available collected through social media. This approach is derived from the awareness that even if the phenomenon of art-led territorial regeneration is recurrent in different countries, there is nevertheless a cultural specificity that can be take into account only through an in-depth interview. The questionnaire through which the interviews were made is structured through 36 specific questions and one possible final open comment. The 36 questions are the same for all three case studies and address several key issues, such as the relevance of geographic location and available heritage resources for the art-related regeneration process, the degree of modification of spaces, the involvement of the local community and possible effects on its self-awareness, the impact of the process in terms of real estate values and the creation of durable jobs, the possible growth of social inequalities as well as regional, national or global recognition of the site. 
Furthermore, in considering art as one of the main engines of territorial regeneration, the focus on the research has been narrowed down to art-related projects developed in small settlements located in peripheral regions. This choice resulted from the recognition that both the shrinkage of vast areas and the belief in the role of culture as a driver for urban economic growth are shared by most long-term, most industrialized countries and economies led to the choice to compare three different case studies at a global scale. Three case studies (Figure 1) distant in geographic terms-Verzegnis in Italy, the Seto Islands (Naoshima, Teshima, Inujima) in Japan, Marfa in the United States-share comparable experiences of regeneration resulting from art-related programs.

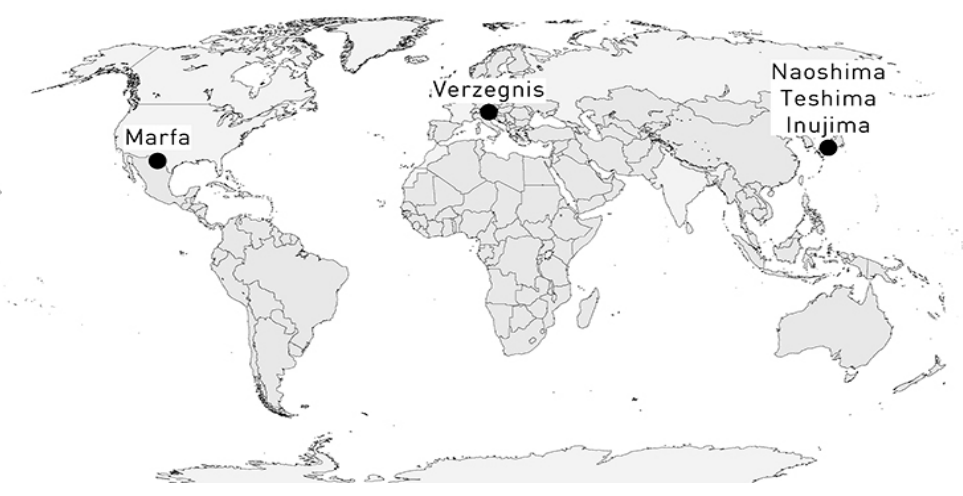

Figure 1. Localization of the three case studies. Map produced by the authors.

Contrary to many case studies derived from middle-size cities or large metropolises where marginalized individuals or communities are systematically encountered, these three case studies are placed in marginal, peripheral territories where social tensions are nearly completely absent or of considerably lower magnitude. So, the main issue to be considered is not so much that of social inclusion as that of innovative art enterprises and their outcome in spatial and social terms.

The three case studies selected to investigate the potential of art as a sparkle for territorial regeneration processes share several key features:

1. They are nested in geographically peripheral areas, so that a certain effort is necessary to reach them;

2. They were initiated between the 1980s and 1990s, and are now decades-long experiences;

3. They enjoy international fame;

4. They were initiated by private individuals (respectively, an art-collector, a tycoon and an artist) and not by public institutions;

5. They are places characterized by a certain tourism of the diaspora (linked to memory, to people's origin and family descent) that is innervated by a tourism generated by a production of alternative desires, of completely new realities, alien to local tradition [47].

Sharing these five features is what makes these specific three case studies comparable and different from other more or less well-known case studies-such as the Giardino dei Tarocchi, the Fiumara d'Arte or Arte Sella in Italy, the Dia Beacon Lighting Field in the U.S.A. or the Isamu Noguchi Garden Museum in the U.S.A., the Hakone Open Air Museum in Japan among the many-distributed all over the world, and in particular in the most industrialized countries.

It is important to underline once more how the choice of three case studies located in peripheral geographical contexts is not an extemporaneous choice, but the consequence of a reflection on the patterns of development and concepts elaborated in the different research and experiences above mentioned. Furthermore, the choice to compare different case studies at a global scale not limited to a specific country or culture might allow the 
research to investigate if art as an engine of territorial regeneration can be considered a universal model for the most industrialized countries and economies and if so which different paths and patterns such a regeneration process can take.

\section{Case Studies}

\section{1. $A$}

Villa di Verzegnis is a small village counting 181 inhabitants and is part of Verzegnis, a municipality with 875 inhabitants located in Carnia, a mountain area in Friuli-Venezia Giulia region in north-eastern Italy. Between 1987 and 1989, the American artist Bruce Nauman completed in Villa di Verzegnis the Truncated Pyramid Room, the first of a series of site-specific works located in the Art Park or better, Art Lawn [48] (p. 94) (Figures 2 and 3).

The Art Lawn has been established after a dialogue between two German people, Egidio Marzona - one of the most relevant art collectors worldwide-and the gallerist Konrad Fischer. Marzona's family emigrated during the first half of the 20th century in Germany from Carnia, an alpine region in north-eastern Italy. As a consequence of his passion and immersion in the artistic environment of Düsseldorf in the 1960s led by the figure of Joseph Beuys, the self-taught Egidio Marzona has become a publisher and art collector, building up a collection mainly composed of American Minimal, Conceptual and Land art that in more recent years has expanded towards the European (both Western and Eastern) Post World War II scene. Marzona started at the end of the 1980s to ask some artists from whom he already purchased works as Bruce Nauman, Carl Andre, Richard Long, Laurence Weiner and Dan Graham among others to create sculptures to be placed outdoor in Villa di Verzegnis, in the property that once belonged to his family that he reacquired over time.

The lawn where the majority of works are located has peculiar qualities: on one side, it matches with the spatial features of many other small villages of Carnia, with uninterrupted continuity and absence of clear borders between the urban tissue, the cultivated and the wild lands, on the other, it is related to a very specific tragic memory, since after the 1976 earthquake in Friuli-Venezia Giulia in the lawn were located prefabricated housing units for the evacuees. Today the Art Lawn, completely accessible all year round for free at the disposal of locals and visitors, hosts around fifteen sculptures and in the intention of his promoter, is a work in progress in continuous expansion.

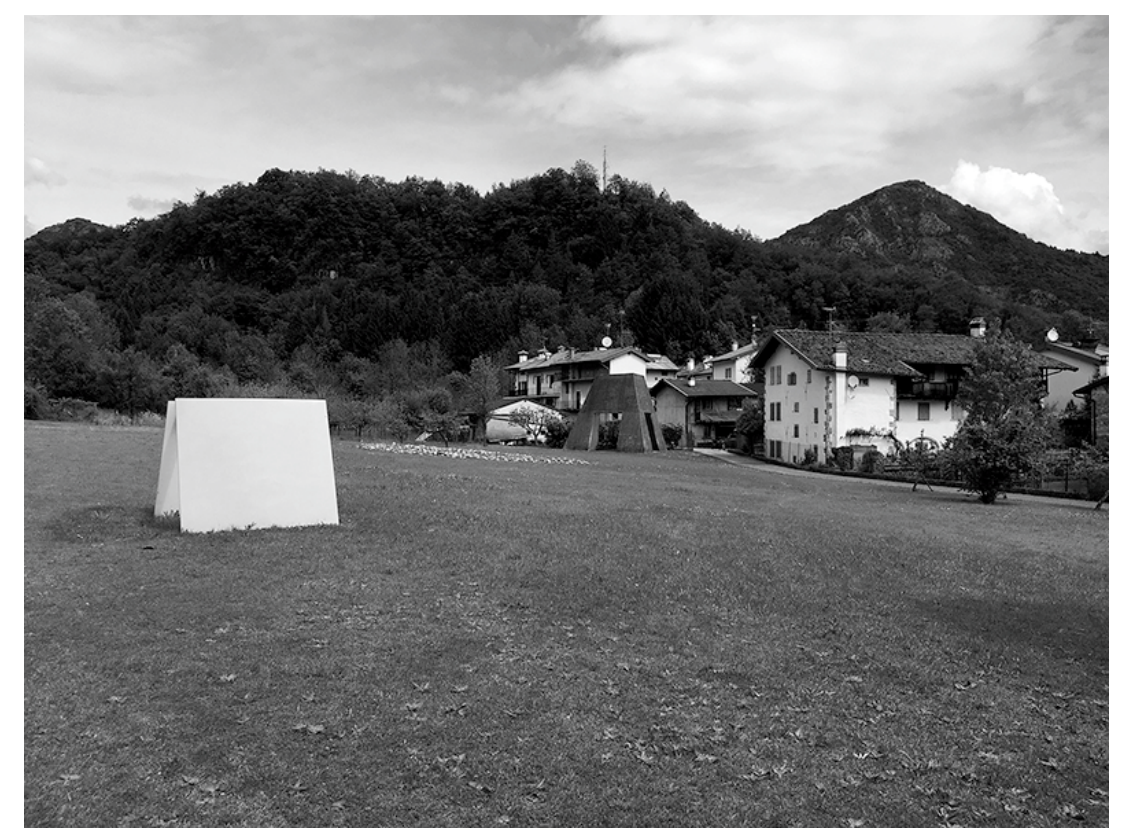

Figure 2. Two works located on the Art Lawn in Villa di Verzegnis. Picture by the authors. 


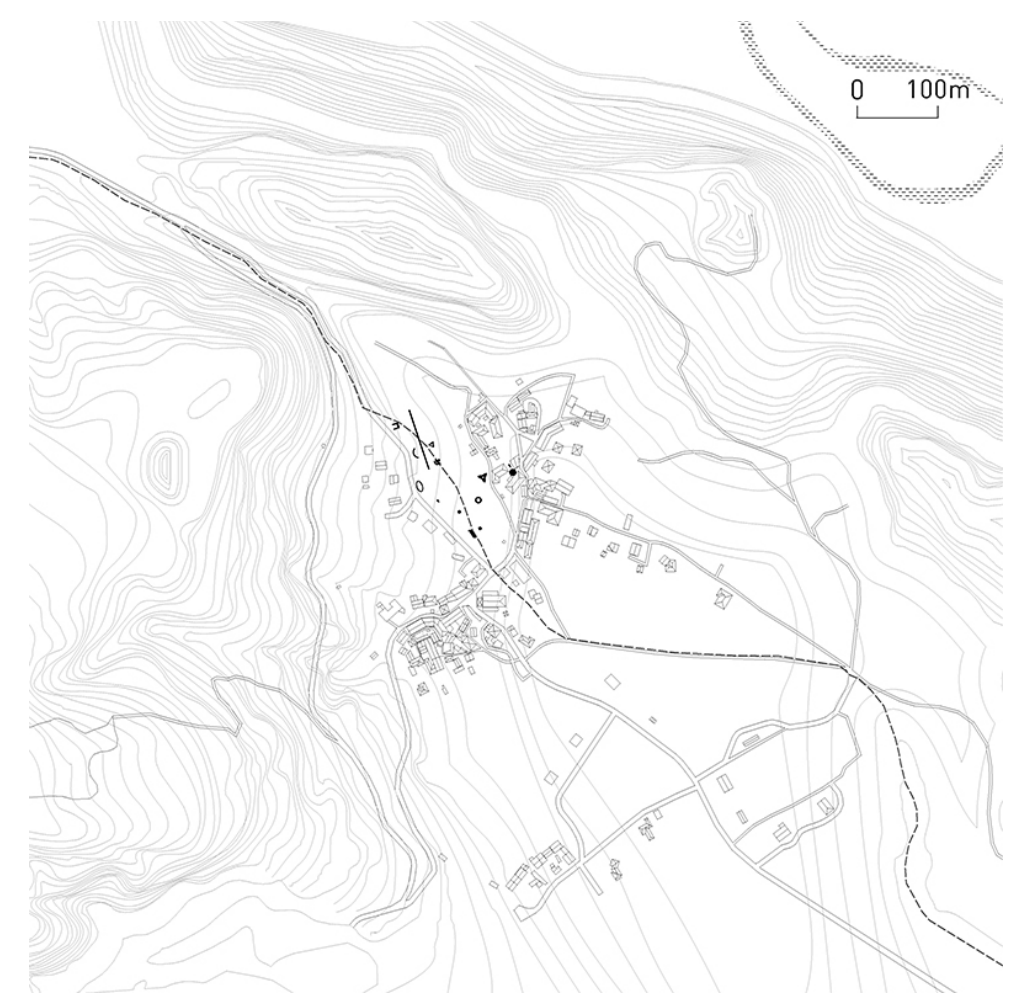

Figure 3. Map of Villa di Verzegnis and localization of the art works. Map produced by the authors.

\section{2. $B$}

Naoshima, Teshima and Inujima (respectively, 3.117, 800 and 47 inhabitants) are three islands among the hundreds that make up the archipelago of the Seto Inland Sea of Japan (Figure 4). Since the mid-1980s, the Japanese billionaire Soichiro Fukutake, driven by a cultural attachment inherited from his father, decided to turn his interest in contemporary art towards these islands of his childhood.

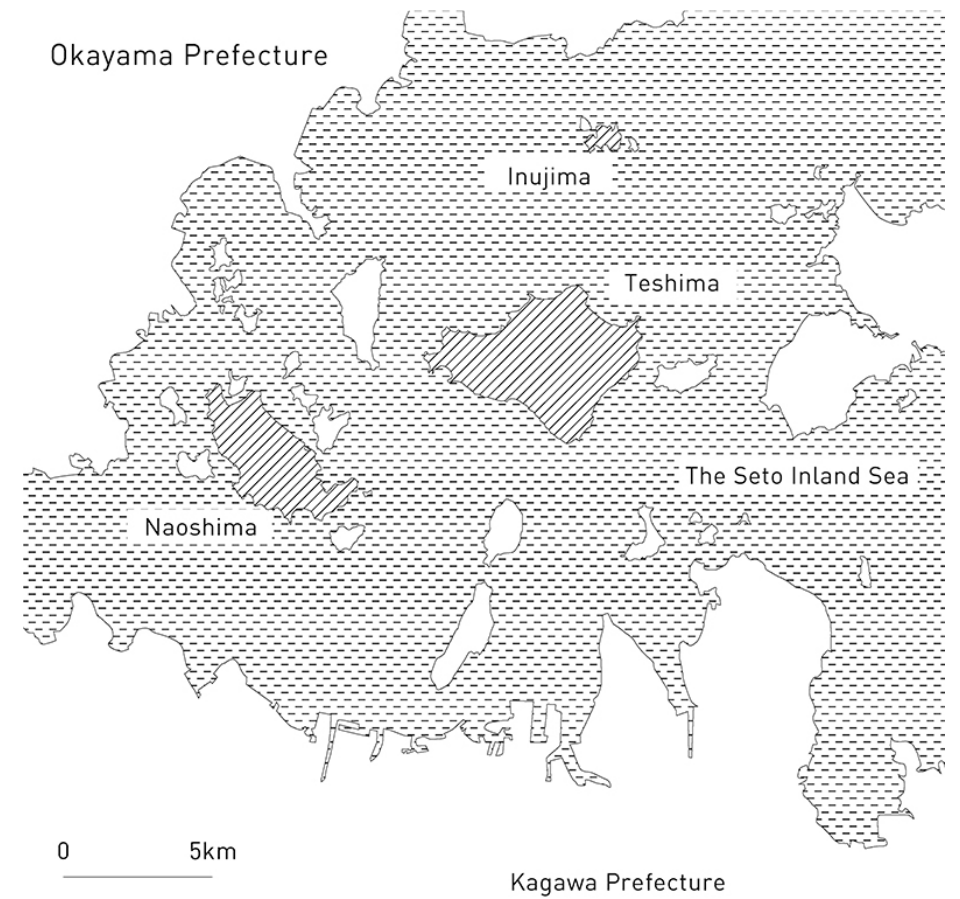

Figure 4. Location of the islands of Naoshima, Teshima and Inujima in the Seto Inland Sea. Map produced by the authors. 
Although he had never lived there, the goal of the billionaire and former chairman of the Benesse Corporation, a publishing firm and juku company, was to transform the three islands, which in the last decades have witnessed both depopulation and failure of local economic activities, in cultural centers of international interest (Figure 5).

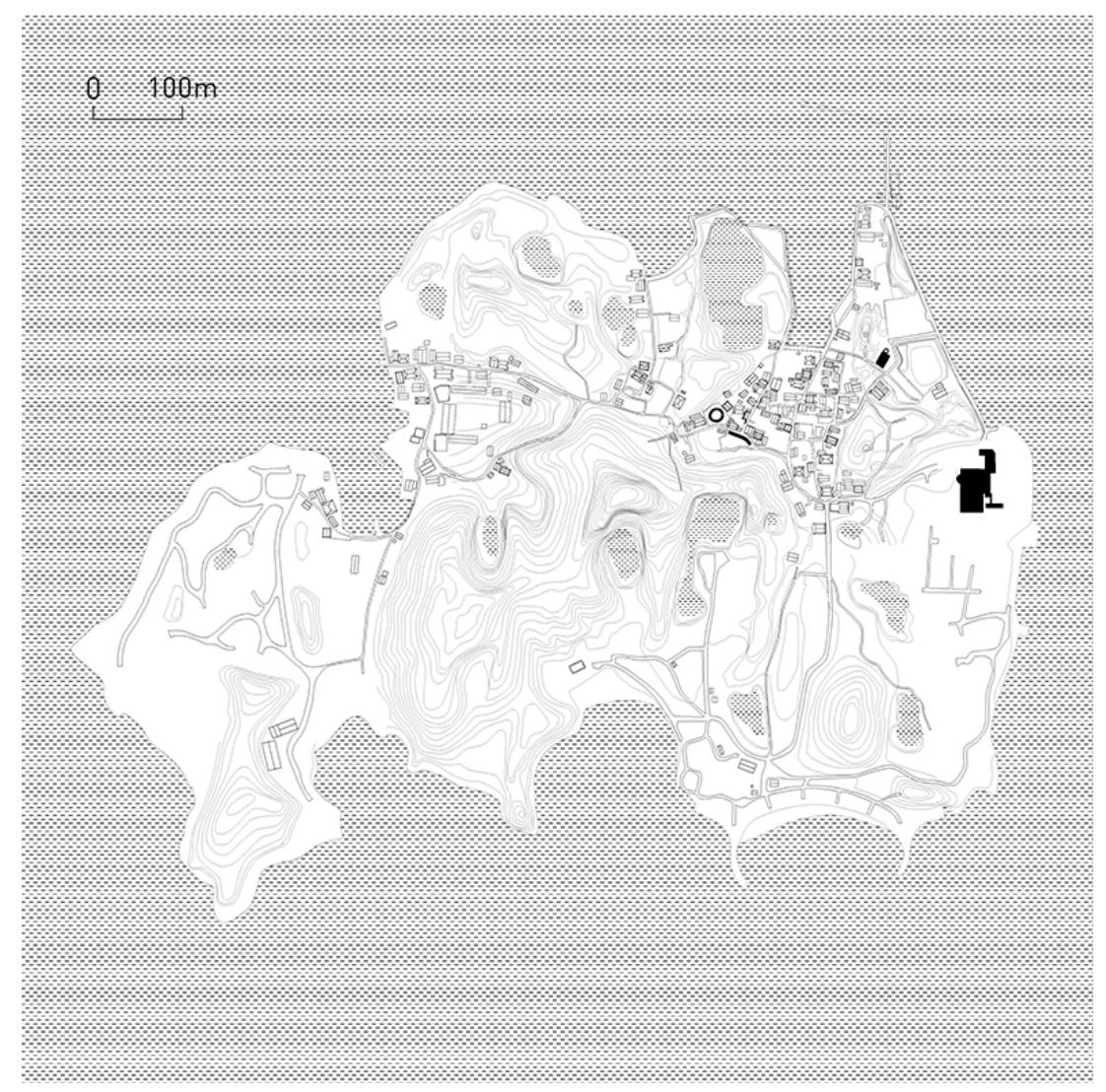

Figure 5. Map of the island of Inujima with the different projects developed over the recent years. Map produced by the authors.

This is how the Benesse Art Site project was initiated and then supported by the Fukutake Foundation [49]. From a first investment in museum and hotel facilities dedicated to a selected clientele attracted both by the selection of celebrated artists and by the landmark buildings designed by the Japanese architect Tadao Ando, the plan has evolved to involve every aspect of the local context (Figure 6). Subsequent interventions have invested in the landscape and restoration of the agricultural heritage of the rice fields on the island of Teshima, the traditional architecture of the Art in House Projects developed in the villages of the three islands that see the restructuring and re-use of ancient rural buildings and society, the involvement of indigenous people through active associations and that of visitors through educational programs aimed at making the local knowledge and lifestyle known. The Benesse Art Site has been, in the past years, advertised through exhibitions all over the world, and temporary cultural events amplify its visibility especially among the Japanese population.

Today, Naoshima, the first island to be interested by the program with the construction of Ando's buildings, is the main point of arrival for visitors. Tourism has encouraged the development of small catering and bicycle rental activities, as well as the birth of artistic and craft activities. Teshima, once notorious for a soil pollution scandal, has rediscovered its original link with agriculture, and houses an innovative exhibition structure designed by Ryue Nishizawa. Inujima, which covers an area less than a square kilometer wide, has evolved from its mining past into a widespread museum, hosting works by Japanese artists and architects as Yukinori Yanagi, Hiroshi Sambuichi and Kazuyo Sejima [50]. 


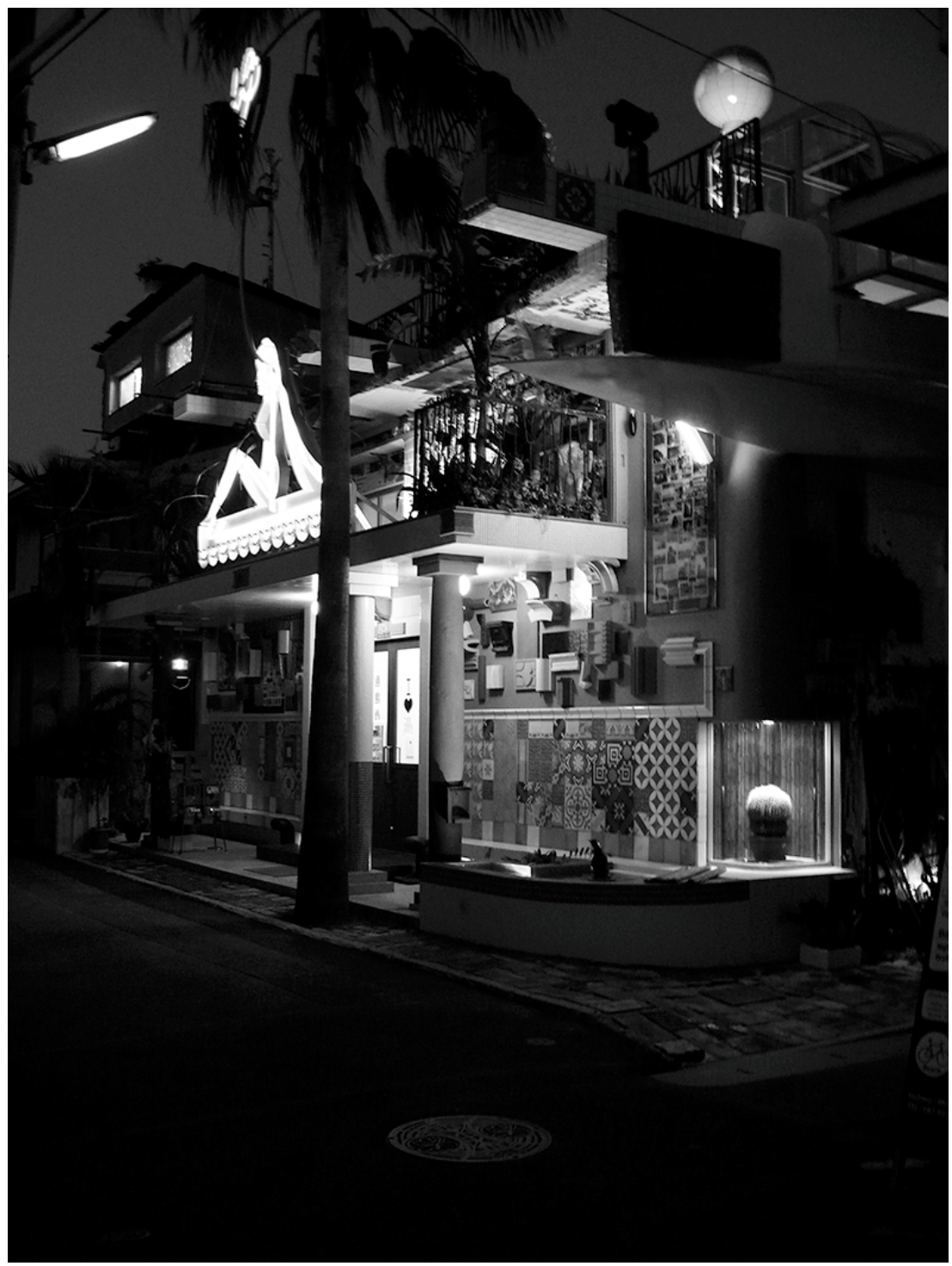

Figure 6. The Naoshima Bath by Shinro Ohtake. Picture by the authors.

\section{3. $C$}

Marfa is a small town of 1625 inhabitants located in the Trans-Pecos desert region in Texas, not far from the Mexican border (Figure 7). The artist Donald Judd, born in Missouri and based in New York City prior to his relocation in south-western Texas in the mid of the 1970s, stated plainly the reasons that brought him to develop his project in Marfa and give birth to the Chinati Foundation: "The purpose of the foundation is to preserve my work and that of others and to preserve this work in spaces I consider appropriate for it. This effort has been a concern second only to the invention of my work. Additionally, gradually the two concerns have joined, and both tend toward architecture. The installation of my work and of others is contemporary with its creation. The work is not disembodied spatially, socially, temporally, as in most museums" [51] (p. 276). 


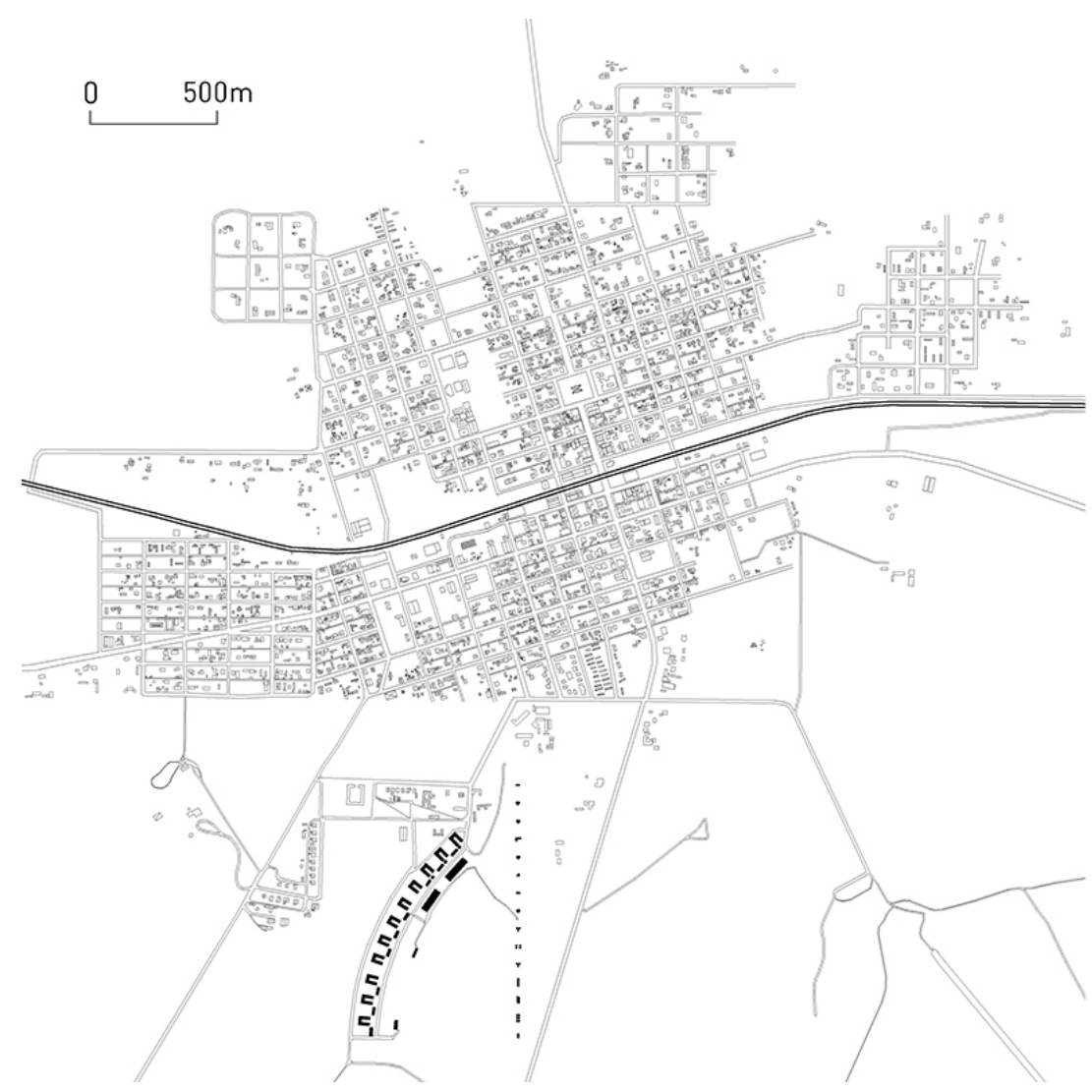

Figure 7. Map of Marfa with the former Fort D.A. Russel on the southern edge of the city. Map produced by the authors.

After World War II and the closure of Fort D.A. Russell, the town of Marfa, located in a majestic and untouched landscape of vast grassy plains in the Presidio County, suffered of a severe economic crisis and demographic degrowth. With the support of the Dia Art Foundation, Judd acquired the former military base of Fort D.A. Russell, fifteen buildings distributed in 350 acres of land that could match his needs. Consequently, to the interruption of the partnership with the Dia Art Foundation in 1987, Judd independently established the Chinati Foundation that became owner of the rights for the artworks as well as the buildings and the land [52] (p. 35).

Judd personally designed and led the renovation of the buildings into living and exhibition spaces. Apart from the 15 works in concrete that punctuate the landscape of the former base (Figure 8), the large majority of the interventions led by Judd did not—or they did barely-modify the exterior appearance of the buildings, operating subtle renovations and contributing to preserve the image of downtown Marfa.

Today his legacy is managed by two separate foundations, the Chinati Foundation and the Judd Foundation, and comprises works by Judd himself, along with John Chamberlain, Roni Horn, David Rabinowitch, Claes Oldenburg and Coosje van Bruggen, Carl Andre and Dan Flavin, among others. 


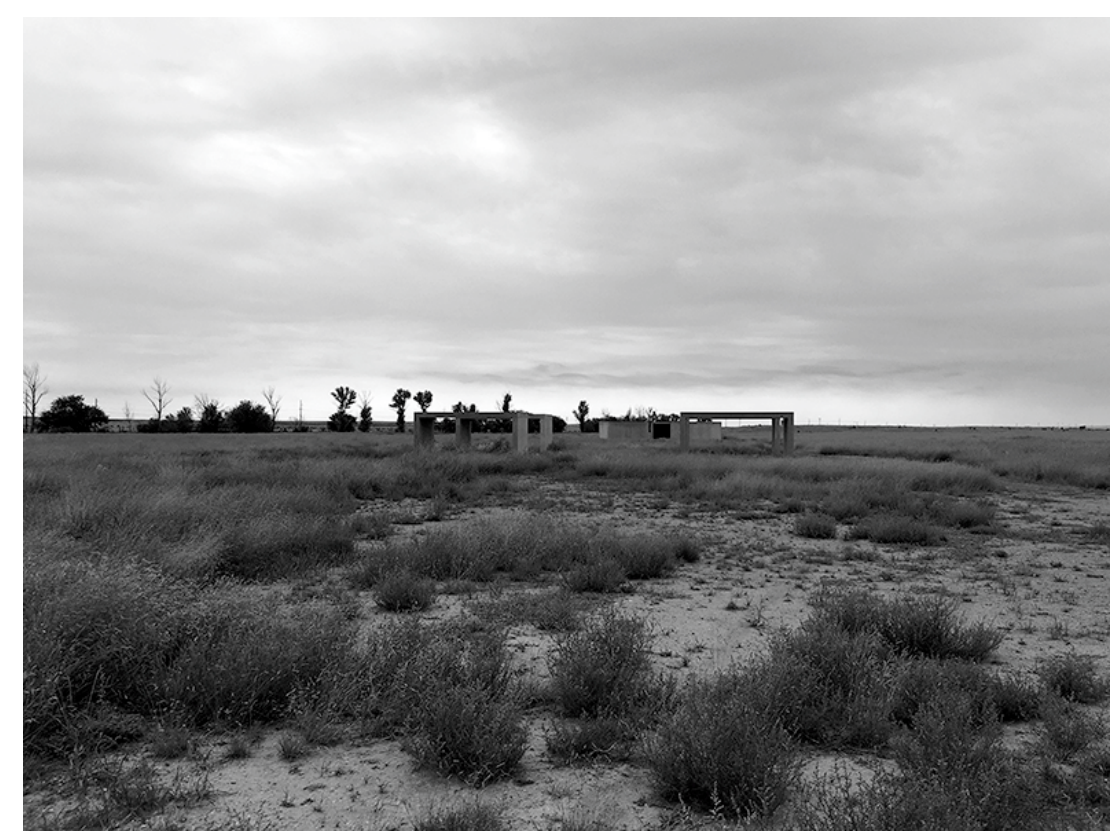

Figure 8. Detail from 15 untitled works in concrete (1980-1984) by Donald Judd located on the grounds of the former Fort D.A. Russel. Picture by the authors.

\section{Questionnaire and Interviews}

The choice to select three case studies located in different continents reflects the intention to test if and under which conditions art as a driver of territorial regeneration can be considered as a model that goes beyond specific cultures and contexts. To accomplish this goal, comparable experiences of regeneration resulting from art-related programs have been selected. In all three case studies a marked originality can be recognized, in line with a widespread and growing need for authenticity far from mass cultural productions, as well as critical skills in the project initiators a collector in Verzegnis, a tycoon in the Seto Islands, an artist in Marfa that generated an action on reality. Another shared fact is that all three projects have been started over thirty years ago, giving a solid base contrary to recent and possibly ephemeral experiences for the research to dispose of a significant time period to be examined. This allowed to verify whether territorial regeneration has actually occurred in and around Verzegnis, the Seto Islands and Marfa with contextual and long-lasting socio-spatial effects, and if there is a relationship between territorial regeneration and social inclusion and spatial justice [53].

Since the goal is to verify the effects of regeneration not only in economic and physical terms - to do so probably having access to local databases and a field survey would be sufficient-but also in social and cultural ones, it is crucial to obtain qualitative and not just quantitative feedback. Consequently, an expansive set of questions has been prepared that relied, in particular, on an attempt developed by Sacco and Crociata [54] to define a framework for the design and evaluation of cultural planning strategies, trying through the questions to hypothesize and identify what is the model or logic chain that allows an art-related project to also become a tool for territorial regeneration. This approach has determined a set of 36 questions recurrent for all the three case studies grouped in relation to three main areas (physical, economic and social regeneration) that address spatial, economic and social issues, plus an additional opportunity to leave more extended comments that have been produced in three languages (Italian, English and Japanese). Consistently with traditional methods of transposition of qualitative judgments into quantitative ones, recently employed also for studies of spatial multi-criteria evaluation of cultural enhancement [55], the range of answers to the 36 questions is based on a scale from 1 to 5,1 being very low/very bad, 5 being very high/very well (Figure 9). 


\begin{tabular}{|c|c|c|c|c|}
\hline 1 & 2 & 3 & 4 & 5 \\
\hline very low / bad & low / bad & average & high / well & very high / well \\
\hline
\end{tabular}

Figure 9. Scale of answers to the questionnaire questions.

Interviews have been made to 15 privileged witnesses (five for each case study) that belong to five different categories:

- Promoters of the artistic programs and processes and professionals who collaborate with them (curators, collectors, artists, architects, critics, etc.);

- Local administration (mayors, councilors, technicians of institutions, etc.);

- Temporary residents (those who return a few weeks or months a year because they have family ties with the place, or because they simply enjoy spending time there, or have short-term jobs);

- Residents who have economic interests (hotels, restaurants, etc.);

- Residents that do not benefit in economic terms from the art-related programs and activities (simple residents).

Thanks to their direct long-term experience and involvement in different roles in the regeneration processes related to art, these privileged witnesses could speak with awareness and insight about how these projects have evolved in the past and might evolve in the future. Given the very limited number of residents and people involved with different roles in these programs, it has been taken a deliberate decision to get through the set of questions in-depth qualitative information from different angles from a limited number of selected witnesses rather than opting for a more extensive-and possibly more superficial in its results-quantitative survey. Even if the research has made use of a structured questionnaire for the purpose of systematically comparing experiences, the time dedicated to the interviews allowed a considerable possibility of in-depth study. The 36 predefined questions (Figure 10) were in fact followed by an open invitation to the privileged witnesses to further explain through a more articulated discourse the issues that they considered more relevant.

\section{Questions related to physical regeneration}

\begin{tabular}{|c|c|c|c|c|c|}
\hline $\begin{array}{l}\text { To what extent do you } \\
\text { think the geographic } \\
\text { location of the town } \\
\text { has contributed to } \\
\text { attracting the } \\
\text { development of art- } \\
\text { related enterprises? }\end{array}$ & $\begin{array}{l}\text { To what extent do you } \\
\text { think the built heritage } \\
\text { of the town has } \\
\text { contributed to } \\
\text { attracting the } \\
\text { development of art- } \\
\text { related enterprises? }\end{array}$ & $\begin{array}{l}\text { To what extent do art- } \\
\text { e related events engage } \\
\text { with the natural } \\
\text { heritage of the town? }\end{array}$ & $\begin{array}{l}\text { To what extent do art- } \\
\text { related events engage } \\
\text { with the built heritage } \\
\text { of the town? }\end{array}$ & $\begin{array}{l}\text { What is the degree of } \\
\text { the involvement of } \\
\text { artists in urban } \\
\text { recovery projects in } \\
\text { the town? }\end{array}$ & $\begin{array}{l}\text { What is the degree of the } \\
\text { reuse of abandoned } \\
\text { buildings in the town } \\
\text { generated by the } \\
\text { development of art- } \\
\text { related enterprises? }\end{array}$ \\
\hline 7 & 8 & 9 & 10 & 11 & 12 \\
\hline $\begin{array}{l}\text { your knowledge, to } \\
\text { hat extent has this } \\
\text { use been carried-on } \\
\text { local firms and } \\
\text { ntractors? }\end{array}$ & $\begin{array}{l}\text { To what extent has } \\
\text { there been an increase } \\
\text { in the use of public } \\
\text { space by local } \\
\text { residents following the } \\
\text { development of art- } \\
\text { related enterprises in } \\
\text { the town? }\end{array}$ & $\begin{array}{l}\text { To what extent has } \\
\text { there been an increase } \\
\text { in the use of public } \\
\text { space by visitors } \\
\text { following the } \\
\text { development of art- } \\
\text { related enterprises in } \\
\text { the town? }\end{array}$ & $\begin{array}{l}\text { To what extent has } \\
\text { there been an increase } \\
\text { in pride, sense of } \\
\text { belonging and } \\
\text { perception of safety in } \\
\text { the private and public } \\
\text { areas of the town } \\
\text { following the } \\
\text { development of art- } \\
\text { related enterprises? }\end{array}$ & $\begin{array}{l}\text { To what extent has the } \\
\text { natural landscape of } \\
\text { the town been } \\
\text { improved by the } \\
\text { development of art- } \\
\text { related enterprises? }\end{array}$ & $\begin{array}{l}\text { To what extent has the } \\
\text { built heritage of the } \\
\text { town been improved } \\
\text { by the development of } \\
\text { art-related enterprises? }\end{array}$ \\
\hline
\end{tabular}

Figure 10. Cont. 


\section{Questions related to economic regeneration}

\begin{tabular}{|c|c|c|c|c|c|}
\hline \begin{tabular}{l}
\multicolumn{1}{c}{13} \\
To what extent has \\
there been an increase \\
in public and private \\
investment in the town \\
following the \\
development of art- \\
related enterprises?
\end{tabular} & \begin{tabular}{l}
\multicolumn{1}{c}{14} \\
To what extent has \\
there been an increase \\
in the level of \\
expenditure of local \\
residents and visitors \\
in the town following \\
the development of art- \\
related enterprises?
\end{tabular} & \begin{tabular}{l}
\multicolumn{1}{c}{15} \\
To what extent has \\
there been an increase \\
in the real estate value \\
of the areas in the town \\
following the \\
development of art- \\
related enterprises?
\end{tabular} & $\begin{array}{l}16 \\
\text { How much have the } \\
\text { art-related enterprises } \\
\text { e contributed to job } \\
\text { creation in the town? }\end{array}$ & \begin{tabular}{l}
\multicolumn{1}{c}{17} \\
To what extent has \\
there been an increase \\
in the capacity to \\
attract and keep \\
companies in the town \\
following the \\
development of art- \\
related enterprises?
\end{tabular} & \begin{tabular}{l}
\multicolumn{1}{c}{18} \\
To what extent has \\
there been an increase \\
in the capacity to keep \\
residents within the \\
region following the \\
development of art- \\
related enterprises?
\end{tabular} \\
\hline \begin{tabular}{l}
\multicolumn{1}{c}{19} \\
To what extent has \\
there been an increase \\
in the capacity to keep \\
graduates and \\
creative professionals \\
within the region \\
following the \\
development of art- \\
related enterprises?
\end{tabular} & \begin{tabular}{l}
\multicolumn{1}{c}{20} \\
To what extent has \\
there been increase of \\
local \\
entrepreneurship and \\
third-sector \\
organizations in the \\
town following the \\
development of art- \\
related enterprises?
\end{tabular} & \begin{tabular}{l}
\multicolumn{1}{c}{21} \\
To what extent has \\
there been an \\
increased \\
heterogeneity of \\
workforce profiles \\
following the \\
development of art- \\
related enterprises in \\
the town?
\end{tabular} & $\begin{array}{l}\quad 22 \\
\text { To what extent has } \\
\text { there been a } \\
\text { development push for } \\
\text { new firms, } \\
\text { commercial and } \\
\text { entertainment } \\
\text { services following the } \\
\text { development of art- } \\
\text { related enterprises in } \\
\text { the town? }\end{array}$ & \begin{tabular}{l}
\multicolumn{1}{c}{23} \\
To what extent has \\
there been an \\
increased involvement \\
of the corporate world \\
in the cultural sector \\
following the \\
development of art- \\
related enterprises in \\
the town?
\end{tabular} & $\begin{array}{l}\qquad 24 \\
\text { To what extent has } \\
\text { there been an } \\
\text { t increased incidence of } \\
\text { partnerships among } \\
\text { public, private and } \\
\text { third-sector parties } \\
\text { following the } \\
\text { development of art- } \\
\text { related enterprises in } \\
\text { the town? }\end{array}$ \\
\hline
\end{tabular}

\section{Questions related to social regeneration}

\begin{tabular}{|c|c|c|c|c|c|}
\hline 25 & 26 & 27 & 28 & 29 & 30 \\
\hline $\begin{array}{l}\text { To what extent you } \\
\text { think the development } \\
\text { of art-related } \\
\text { enterprises in the town } \\
\text { is related to the } \\
\text { history, cultural and } \\
\text { symbolic legacy of } \\
\text { your hometown? }\end{array}$ & $\begin{array}{l}\text { To what extent you } \\
\text { think the development } \\
\text { of art-related } \\
\text { enterprises in the town } \\
\text { has brought radically } \\
\text { new and unforeseen } \\
\text { ideas and practices? }\end{array}$ & $\begin{array}{l}\text { To what extent has } \\
\text { there been a change in } \\
\text { the perceived image } \\
\text { and reputation of the } \\
\text { tow and its } \\
\text { inhabitants by people } \\
\text { coming from other } \\
\text { places following the } \\
\text { development of art- } \\
\text { related enterprises? }\end{array}$ & $\begin{array}{l}\text { How much do you } \\
\text { think has the } \\
\text { development of art- } \\
\text { related enterprises } \\
\text { involved local } \\
\text { residents, increased } \\
\text { their capacity of } \\
\text { expression and } \\
\text { communication of } \\
\text { ideas and needs as } \\
\text { well as self-confidence } \\
\text { and aspirations? }\end{array}$ & $\begin{array}{l}\text { To what extent has the } \\
\text { development of art- } \\
\text { related enterprises } \\
\text { contributed to } \\
\text { increase pre-existing } \\
\text { social tensions or } \\
\text { inequalities in the } \\
\text { town? }\end{array}$ & $\begin{array}{l}\text { To what extent has the } \\
\text { development of art- } \\
\text { related enterprises } \\
\text { contributed to reduce } \\
\text { pre-existing social } \\
\text { tensions or } \\
\text { inequalities in the } \\
\text { town? }\end{array}$ \\
\hline 31 & 32 & 33 & 34 & 35 & 36 \\
\hline $\begin{array}{l}\text { How well do you think } \\
\text { have possible social } \\
\text { criticalities related to } \\
\text { the development of } \\
\text { art-related enterprises } \\
\text { been handled in the } \\
\text { town ( } 1 \text { being very } \\
\text { poorly, } 5 \text { being very } \\
\text { well)? }\end{array}$ & $\begin{array}{l}\text { To what extent has } \\
\text { there been an } \\
\text { enhanced } \\
\text { organizational } \\
\text { s capacity of local } \\
\text { players and a } \\
\text { significant increase of } \\
\text { local social capital } \\
\text { (talent, education and } \\
\text { capability building) in } \\
\text { the town following the } \\
\text { development of art- } \\
\text { related enterprises? }\end{array}$ & $\begin{array}{l}\text { How would you judge } \\
\text { the quality of cultural } \\
\text { supply following the } \\
\text { development of art- } \\
\text { related enterprises in } \\
\text { the town ( } 1 \text { being very } \\
\text { low quality, } 5 \text { being } \\
\text { very high quality)? } \\
\end{array}$ & $\begin{array}{l}\text { To what extent has the } \\
\text { development of art- } \\
\text { related enterprises } \\
\text { improved the quality } \\
\text { of local governance } \\
\text { and reinforced social } \\
\text { networks in the town? }\end{array}$ & $\begin{array}{l}\text { To what extent has the } \\
\text { development of art- } \\
\text { related enterprises } \\
\text { reinforced social } \\
\text { networks between the } \\
\text { town and the world? }\end{array}$ & $\begin{array}{l}\text { To what extent do you } \\
\text { expect the development } \\
\text { of art-related } \\
\text { enterprises to } \\
\text { contribute to an } \\
\text { economically solid, } \\
\text { socially inclusive and } \\
\text { culturally lively } \\
\text { future of the town? }\end{array}$ \\
\hline
\end{tabular}

Figure 10. The set of 36 questions.

\section{Survey Results}

Fieldwork in Verzegnis, the Seto Islands and Marfa allowed us to experience firsthand how the art-related projects have influenced the evolution of the communities in which they were developed and obtain subjective impressions from the different actors and stakeholders. The in-depth interviews provided more objective feedback about points of strength and weakness as well as degree of replicability of each art-related project, the quality of the value generated, the role of planning and design in the overall strategy and creation of value. The total number of responses for each case study is five, totaling 15 interviews. Each of the 15 privileged witnesses replied to all 36 questions assigning a value from 1 to 5 . Several witnesses expressed also further comments in relation to the birth, development and effects of the art-related projects in relation to the case study they were related to.

The arithmetic average of the answers (Figure 11), providing the opportunity to compare the effects of the territorial regeneration for the three case studies in physical, economic and social terms. 


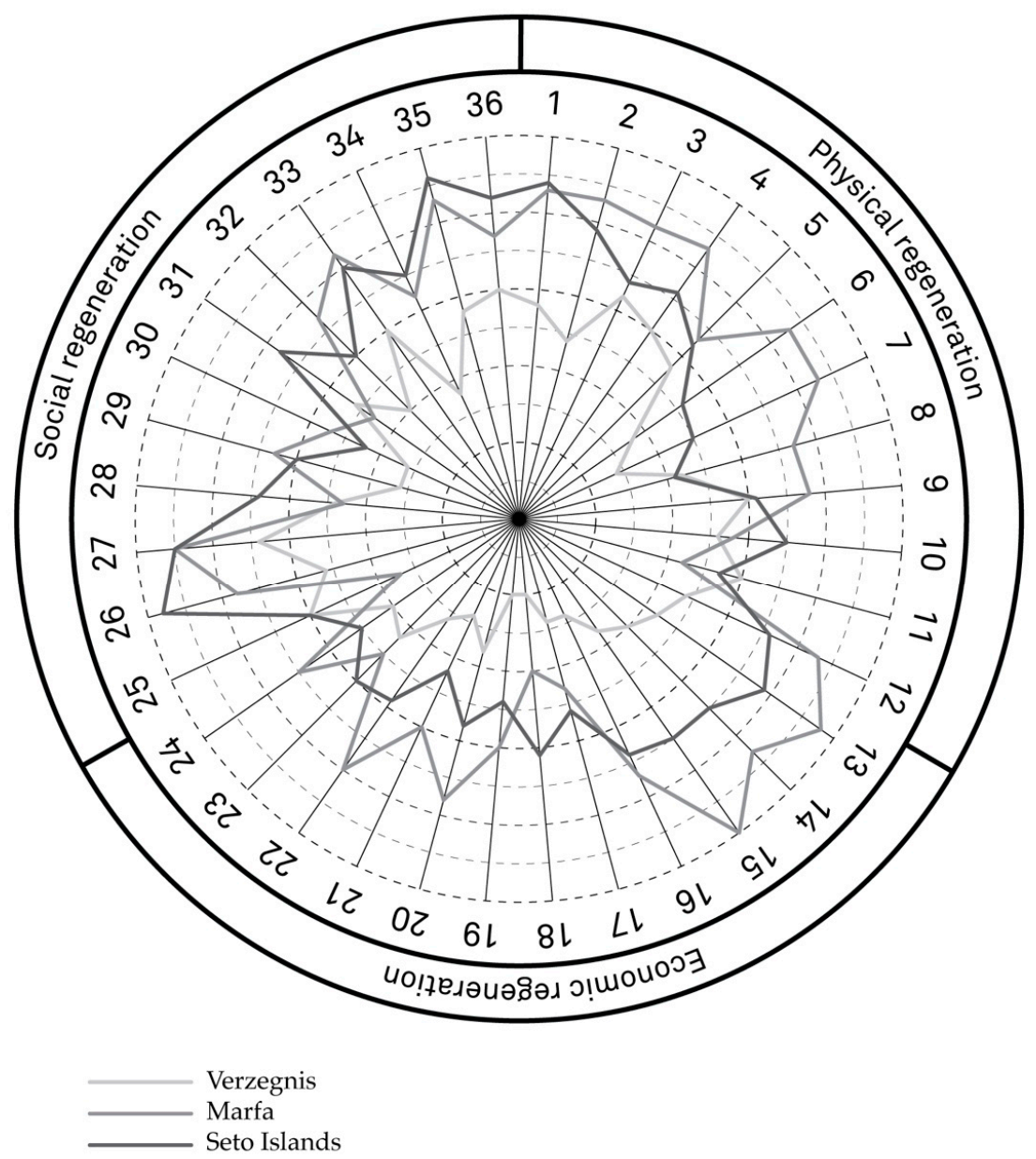

Figure 11. Radar chart produced by the authors synthetizing the average value of the answers given to the 36 questions for the three different case studies. From the interior to the exterior the value goes from very low to medium to very high. Radar charts - or spider charts-were first used in 1877 by the notorious German economist and statistician Georg von Mayr [56] (p. 78). In this type of data representation each star represents a single observation, allowing to display multivariate observations with several variables. Radar charts make immediately explicit through visual comparison relative points of strength and weakness, proving to be particularly effective when employed in the visual representation of indicators of complex subjects, such as cultural heritage [57].

The arithmetic average to the 36 answers for each case study (2.22 in Verzegnis, 3.29 in the Seto Islands, 3.51 in Marfa) gives a first clear idea of the actual degree of regeneration that each art-related program has set in motion. It should be noted then that while the arithmetic average of the evaluations given by representatives of each category in Marfa (ranging between 3.12 for promoters and 3.97 for administration) and the Seto Islands (ranging between 3.02 for residents with economic interests and 3.72 for promoters) is quite close and relatively high, in Verzegnis the arithmetic average to the evaluations given by representatives of residents that do not benefit in economic terms, temporary residents and residents with economic interests $(2.25,1.83$ and 1.77 , respectively) is significantly lower than the ones resulting from administration and promoters (2.55 and 2.72).

While considering the results of the in-depth interviews in Verzegnis, the first immediate outcome then is the recognition of the low degree of involvement of the local community in the regeneration process. In fact, the privileged witnesses showed a certain understatement if not overt criticism-in terms of recognizing the qualities of the built heritage and landscape as a background for Marzona's Art Lawn. Reading through the answers-this outcome is further confirmed by our fieldwork-it is also clear how the art-related project did not have significant outcomes in terms of re-use of abandoned 
buildings and general improvement of the building stock. Following this same trend, it is evident that the economic impact of the Art Lawn has been quite low in terms of increase of public and private investment, level of expenditure of residents and visitors, real estate value, creation of new and diversified firms, services and, consequently, jobs. Under the social angle, if on one side it is noticeable a scarce improvement in the quality of local governance and interconnection between the private and public sector, on the other it was recorded the absence of social tensions and inequalities and the recognition of a certain continuity in cultural and historic terms between the Art Lawn and its context. From the open comments at the end of the questionnaire emerged a halo of skepticism in relation to the scarce impact the program promoted by Egidio Marzona had in physical, social and economic terms in the tissue of Villa di Verzegnis and its neighboring villages. A resident with economic interests with a previous long experience as local and regional administrator that we interviewed affirmed that "the institutional system has scarcely addressed the involvement of local stakeholders in the activities and programs promoted by Egidio Marzona. There has barely been interaction and transmission of information about the accomplished goals between the promoters, the local authorities and the community." This observation may also be linked to the fact that Marzona himself seemed to never fully play the role of social entrepreneur [58-60], relating and possibly relegating over the years his actions in first place to an autobiographical discourse.

The outcomes of the survey conducted in the Seto Islands show that the local residents and the new inhabitants attracted by the development of the art-related program led by the Fukutake Foundation assigned a significant role to the geographic location of the islands and their natural and built assets as a starting point for this initiative. More than this, they stated that these assets have been improved thanks to this long-term program that also contributed to an increase of pride, sense of belonging and perception of safety in the private and public areas of the islands. Coherently with these first outcomes, it is evident how along with a substantial increase in public and private investment in the Seto Islands the art-related enterprises have contributed to create new jobs and keep residents within the region. Moreover, these enterprises brought radically new and unforeseen practices and ideas that have dramatically changed the perception and reputation of Naoshima, Teshima and Inujima. These new practices did not bring social tensions: on the contrary, there has been an augmented level of involvement, the capacity of expression and self-confidence of local residents, increased attractivity of the area. As a resident that we interviewed testified: "Five years ago, I moved from Tokyo with my family in search of a good environment for raising children. In Japan, the problems of demographics declining birthrate and aging population and vacant houses are serious ones, and Naoshima also has such problems. In order to revitalize Naoshima in a sustainable manner, it is necessary to renovate vacant houses with hard-working people from all over the world and create manufacturing schools that can be attended by men and women of all ages. Today, Naoshima is crowded with tourism, but the tourism industry alone does not enrich Naoshima. I think the best investment is to educate: schools can be considered as a place for that purpose. Instead of simply creating new things, I think that Naoshima's policy of making existing vacant houses available little by little and possibly having schools to further implement this process scattered around the city is very promising. By doing so, I think that it will be possible to become a one-of-a-kind island like no other in the world."

Fieldwork has made these aspects suggested by the Naoshima resident stand out in an even stronger way, showing how all generations of citizens, from teenagers to elderly people, were actively engaged in activities related to the maintenance and repurposing of built and landscape heritage and making possible the visit and experience of the artworks and art sites, often hosted in the same renovated buildings. This generated an improvement in the quality of local governance, a reinforcement of social networks, and the strong belief in the fact that art-related projects could lead to a positive future, inclusive in all terms.

In the case of Marfa, there is a strong awareness in recognizing the qualities of the built heritage and landscape as a crucial asset in attracting art-related programs, led by Donald 
Judd first and then by the others that followed both in the Chinati and Judd Foundations as well as in other independent galleries. Here, it stands out a high volume of reuse and improvement of abandoned buildings, often carried out by local contractors. Inevitably this went along with a radical increase in private investment and level of expenditure of visitors, the creation of new jobs and sky-rocketing real estate values. These facts immediately catch the eye by simply visiting Marfa, looking at the advertisements in the windows of real estate agencies or having a drink on the premises one can immediately notice the difference in terms of living costs compared to nearby cities, such as Marathon or Alpine. Reporting the point of view of a resident with economic interests that we interviewed: "Marfa depends upon a large number of visitors to support the arts through local businesses such as restaurants, overnight stays, food purchases, gasoline, book purchases, campgrounds, during weekends primarily. However, we are also seeing more wedding parties in town as time goes on. When and if there is a slow down in the US economy it is very obvious that these visitors would not come in the same numbers as in good economic times. Without visitors the bare bones of Marfa's residents may find employment scarce as well as employers finding their incomes reduced. Marfa is very far from large cities: 10 or 12 hours drives from Dallas, Austin, Houston. However, the mega rich are moving into Marfa and increasingly buying property, flying into the Marfa airport and staying longer. This phenomenon is similar to what happened in Santa Fe, New Mexico in the early 1990's when California's economy went down. People leaving California and heading to the intermountain west as far as Denver changed the USA forever, Marfa too."

On the one hand, this economic boom has contributed to evolving the entrepreneurial capacity of local players and augmenting the presence of third-sector organizations; on the other, it has contributed to exacerbating social tensions, and that was of a modest entity before the boom of art-related development in this small Texan town. If, as anticipated, the natural and built assets of Marfa, in the opinion of the persons being interviewed, have contributed to attracting the art-related programs, in turn, it seems that the development of these same programs is very loosely connected to the historic, cultural and symbolic legacy. Following the art-related regeneration process, it has been noticed a clear positive effect in terms of the notoriety of the Texan town, reinforcement of its social and cultural networks on a global stage and improvement of cultural supply, but it emerged a weaker belief in the possibility that this would lead to an inclusive future (Figure 12).

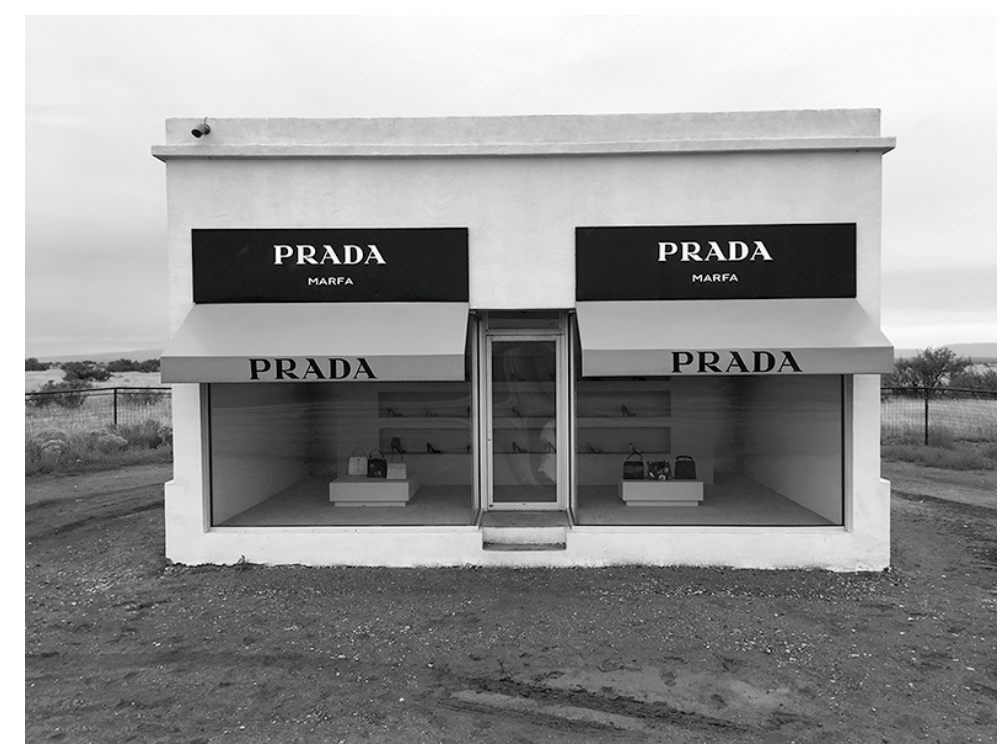

Figure 12. The Prada Marfa permanent installation (2005) by Elmgreen \& Dragset. The work is an ironic reaction to the economic boom related to the art world experienced by the small Texan town in the recent decades. Picture by the authors. 


\section{Discussion}

All of the three case studies result from the implantation of a discontinuity through artrelated programs that marked an act of rupture with pre-existing shrinking mechanisms and patterns. Following different trajectories, they accomplished to a higher or lesser degree what can be defined as an "articulated territorial perspective at both the local level characterized by an idiosyncratic mix of factors that doesn't concern only current local characteristics and global levels simultaneously, weaving their specific narratives, spheres of meaning, cultural milieu and socio-economic factors, into a common analytical framework" [44] (p. 2815).

In Marfa, the effort made by Donald Judd to integrate landscape, architecture and art has generated an increasing flow of tourists and a maybe unexpected real estate boom. The transformation of the former military base, a public real estate asset, led to a very partial and socially unbalanced form of wider urban regeneration [61,62]. Old buildings have been turned either in art galleries, commercial spaces or second homes with contemporary designs. In turn, Marfa has become such a fashionable destination for art-related tourists that even the number of wedding parties of people coming from the east and west Coast is rising. As suggested by one of the local experts that have been interviewed, this touristic growth is not a mere passenger trend but the result of long-term phenomena that hit already in the 1990s a city as Santa Fe, New Mexico of relocation of very rich people in the intermountain west. This same local expert is also deeply aware of the fact that "when and if there is a slowdown in the US economy it is very obvious that these visitors would not come in the same numbers as in good economic times. Without visitors the bare bones of Marfa's residents may find employment scarce as well as employers finding their incomes reduced." The pandemic that hit the whole world in 2020, if possible, underlined even more how the one of Marfa is mainly currently a business-oriented model, to the point that tourists are not discouraged to flock in the city even if the COVID-19 related cases were booming [63].

The north American case study shows how the innovation initiated by art generated an economic boom that brought with it growing social tensions and the exclusion of a significant amount of local population from economic profit. An increasing gentrification that has been recognized also by the artists community, so that it has become the subject of a video by the French artist Lily Reynaud-Dewar and her students [64].

On the opposite, a different development path unfolded in the case of the Seto Islands, marked by a stronger community character, thanks to a process that has been implemented since the beginning through meditated and guided steps. Not only the project launched by Fukutake, who decided to invest in art as a vehicle for the transmission and preservation of a culture in extinction, has started a chain of investments and initiatives in constant development, but has also earned the advantage of being very well integrated with the local population-more and more elderly — that today feels part of the new life of the islands.

The case of the Seto Islands is an example of cohabitation between two realitiesthe global one of contemporary art and the pre-existing local fisherman and industrial community - on the basis of care for landscape and cultural heritage and their preservation. The attention and care that the inhabitants give to the artworks on the islands determines for the visitor a completely different experience, encouraging longer stays that benefit local economic activities. However, it also means a necessary involvement of the local population in the project, and it is in this relationship between inhabitants and works that tourism success or failure resides. A multitude of associative activities were born, above all related to food and hospitality, which involve the elderly left on the islands and young newcomers who move from the Japanese metropolises, which have opened up innovative catering and floriculture activities there. One of these young people explained with great clarity how "Naoshima (and the other two islands too, it could be said, ed.) is crowded with tourist visits, but Naoshima cannot become rich with tourism alone. I think that to make these islands unique in the world the key is education, linked to art or to other disciplines." 
Except for major projects such as the Chichu Art Museum designed in Naoshima by Tadao Ando or the museum created for Teshima by Ryue Nishizawa, the artistic works have been carefully inserted into the urban fabric, filling the gaps between buildings. There is no kind of fence or barrier to separate the public land from the cultural path to the point that the difference between the works of Land Art or the installation with the local private architecture is visually subtle. The urban integration of art also meant a more spontaneous engagement with the works, which become playgrounds for children and spaces for socializing outdoors for the elderly.

While in the Seto Islands the exhibition routes unfold at different points, forcing the visitor to cross all the villages, at Villa di Verzegnis the topography of the ground suggests several possible routes within a more compact exhibition area, establishing as in the Japanese case study and in some moments also the Texan one-a dialogue with the surrounding landscape.

If the art works commissioned by Egidio Marzona since the end of the 1980s are well integrated with the context where they are located, often the production of these same works has not been accompanied by a public presentation with direct involvement of the local community. Occasional events, exhibitions and an international conference [65] have been organized by Marzona, in both Villa di Verzegnis and the nearby city of Tolmezzo, but without a planned schedule over the years. The lack of an explicit long-term vision-as the one of a social entrepreneur-has probably penalized the promotion of the Art Lawn over the years, to the point that even in between the borders of Friuli-Venezia Giulia region, a conspicuous amount of population is not aware of its existence. The cultural projects carried out in Verzegnis have been different in recent years but have barely succeeded in taking root. In 2018, an event as the "Music Art Park" tried to establish stronger bounds with the territory aiming at creating a network comprising also actors apparently far from art but that could in the coming years support the efforts of the Marzona family in promoting this experience. The answers given to the set of questions confirm that in Verzegnis there is still weak feedback since the initial spark promoted by the private sector did not find a reactive counterpart in the local administration. In the words of a local businessman that had also relevant political experiences at the regional and national level, "the institutional system has contributed little to the involvement of local realities. There has been little interaction and transmission of what has been achieved with the Art Lawn". In the Italian context this is a kind of recurring pattern, as also another internationally known experience as the one of Favara testifies [66].

In conclusion, it could also be said that the different case studies considered respond or match with different possible models of regeneration of shrinking peripheral territories: if attention is focused on economic results, there is no doubt that Marfa with its booming real estate and network of private foundations and art galleries attended by affluent tourists represents the most effective model at least for a relatively small group of people. If looking for a more inclusive model that does not increase or even reduces, as in the Japanese case, social tensions and inequalities, it is at the case studies of Verzegnis and Seto Islands that attention should be turned. Yet, these two latter experiences should also not simplistically be considered as too close, since the degree of engagement of the local administrations and communities proved to be significantly different.

Referring to the initial research question namely to verify how and to which degree art-related programs can significantly have effects in terms of territorial regeneration of shrinking regions a first provisional comment related to the three case studies taken into consideration could be attempted: only when private and public actors find a way to profitably collaborate and each part involved fully believes in the effort the redevelopment process through art-related programs achieves its full potential. This implies that original regeneration sensitive towards the local community and imaginative in the way it interacts with the built and landscape heritage is first of all a political process that requires local government actions and community mobilization. 
At the time being, only in the Seto Islands an original project gave evident and shared results: a project developed with a long-term view, sensitive towards the local community and original in the way it interacts with the built and landscape heritage. Here the past is neither denied nor canceled. On the opposite, it is imbued and enriched with contemporary art and knowledge. Contrary to other case studies were grassroots initiatives paved the way to the corporatization of space [67], in the Seto Islands an alternative and inclusive future was constructed following a clear vision by initiative of a private corporation. A future built with patience on solid foundations as collaborative activities, beauty and trust. The resulting sense of belonging deriving by the sharing of a goal and responsibilities has, therefore, dramatically increased the social capital in this Japanese archipelago. Quite on the opposite, in the Italian case study it is recognizable a condition of stasis, where the local administration and community seems to have no will to dialogue with, to understand the proposal of Marzona. The initial "gift" from Marzona has been neither understood nor accompanied, with the exception of few individuals who cyclically attempted to build around the Art Lawn a more solid network based on art related programs in Verzegnis.

There is no doubt that after this first balance emerges a set of issues that should be investigated more in depth, and that might constitute a relevant reference also for other case studies [68]. Issues such as the possibility of expanding the number of people to whom the set of questions is submitted, the initial focus on art of these programs and its balance over time with a diverse range of activities that resulted from it (tourism, food, real estate business, etc.), the evolving relationship between private individuals or institutions and the public sphere, the political relevance of these programs and their durability.

\section{Conclusions}

The influential curator and art historian Harald Szeemann described effectively the process initiated by Egidio Marzona in Villa di Verzegnis and the same words could perfectly match also with the other two case studies: "This transfer of a private passion into a new collective dimension can not be achieved without awakening resistances. Only time can allow that the amazement and surprise of the community in the face of the exemplary and surprising initiative of the individual transforms into a collective cultural experience. All this rarely happens without the original initiative of a private individual that, ideally and concretely, slowly transforms into collective heritage" [61] (p. 29).

Szeemann, without a doubt, hit the spot: in the kind of regeneration through artrelated programs taken into consideration, the role of the single private is crucial as initiator and engine of the process. Public administrations and institutions - and here the comparison between Verzegnis and the Seto Islands is revealing-are then fundamental in sustaining these kinds of programs and enabling the establishment of a network of "connectors", of figures that given their different skills and interest contribute to the survival and expansion of these experiences. These are indeed expensive programs, both in terms of economic resources and time and energies spent in the shaping of awareness and coordination of efforts towards durable and tangible outcomes. Expensive programs that require the recognition of culture as a strategic public policy tool, possibly sustained by institutions and inter-governmental organizations, such as the Council of Europe and UNESCO, as well as national states. It is significant in this sense to note how over the last two decades the European Commission has significantly pushed its cultural policy agenda, generating significant outputs and contributing to the creation of jobs $[69,70]$.

Art-related regeneration processes-in the form of works, events and cultural programs - can be brand new or result from the interpretation of the landscape and built environment. In Villa di Verzegnis, the Seto Islands and Marfa can be recognized the introduction of a discontinuity that operates following that need of authenticity opposed to mass productions that permeates in the recent decades our societies [71] (pp. 529-546). Studying the outcomes of the initiatives of Egidio Marzona, Soichiro Fukutake and Donald Judd it can be recognized, as suggested by Szeemann, a recurring pattern where a strongly motivated individual activates a project that generates an artistic outcome in 
form of permanent works and temporary events and performances. This initial effort in the cultural sphere permeates then the local context, affecting with variable results the economic and social life of the communities. The investment in culture does indeed modify space, not only through its most obvious and visible consequence-the installation of works of contemporary art-but activating a more pervasive process of reconfiguration of the built heritage as well as push to the development of enterprises in the touristic field (restaurants, bars, hotels, B\&Bs).

The experiences of regeneration through art and culture considered did not rely so much on the resources physical as well social and economic already available on site but operated through the implementation of innovative programs that generated quite different results. If in the Italian case, the art-related project barely contributed to the regeneration of the built heritage, and in the Texan case, is evident a real estate boom that sensibly increased tensions among different social groups, in the Japanese case, the process of rehabilitation and modification of space has been so pervasive that also the landscape has been invested by it. These considerations derive from an initial exploration and can become the source for more in-depth research on the subject. The preliminary comparative analysis of the three case studies seems to suggest how globally art and more generally culture is indeed a lever for territorial regeneration. This lever determines profoundly different processes also due to the nature of the context, the orientation of the project promoter, the ability of a community to appropriate and further develop and sustain the initiative.

It is important to underline that from these case studies it cannot be inferred that there are three distinct European, Japanese and American models. These are models that may have occurred in other places, not predefined on a cultural basis. Even if the three specific case studies are indissolubly related to three specific initiators and geographical contexts, they break away from national issues to become universal models. They suggest that art could be one of the main engines of territorial regeneration in the most industrialized countries, and possibly also at a global scale, only if sustained by enduring local government actions and community mobilization.

Author Contributions: Conceptualization, L.C. and E.M.; methodology, L.C. and E.M.; investigation, L.C.; resources, L.C. and E.M; data curation, L.C.; writing — original draft preparation, L.C.; writingreview and editing, E.M; visualization, L.C. and E.M.; supervision, E.M.; funding acquisition, E.M. All authors have read and agreed to the published version of the manuscript.

Funding: Research funded by the program PRIN 2015, protocol 2015STFWFJ_004, titled “Le città metropolitane: strategie economico territoriali, vincoli finanziari e rigenerazione circolare", supported by MIUR (Italian Ministry of Education, University and Research).

Institutional Review Board Statement: Not applicable.

Informed Consent Statement: Not applicable.

Data Availability Statement: The datasets used and/or analysed during the current study are available from the corresponding author on reasonable request.

Acknowledgments: The authors would like to thank all the people who made possible with their help and suggestions the production of this paper. Eva Basso, Silvia Dessenibus and Troy Schaum have played an important role in introducing us to the contexts, respectively, of Villa di Verzegnis, the Seto Islands and Marfa. Victoria Easton, Juan Herreros, Peter Staub and Verena von Beckerath provided precious suggestions in regard to the phenomena of shrinking cities and regions. Egidio Marzona and Elena Carlini kindly found the time to discuss informally about the experience of the Art Lawn in Verzegnis, while Tomomitsu Takeuchi translated in Japanese the questionnaire submitted to the Seto Islands privileged witnesses. Patrizia Gridel and Michel Zuliani of the Unione Territoriale Intercomunale della Carnia provided cartographic materials of the Verzegnis municipality. The authors thank all the 15 privileged witnesses in Villa di Verzegnis, the Seto Islands and Marfawhose names we maintain anonymous to respect their privacy - who found the time to answer the questionnaire and make additional comments in relation to the subjects treated in the essay.

Conflicts of Interest: No potential conflict of interest was reported by the authors. 


\section{References}

1. Yudice, G. The Expediency of Culture: Uses of Culture in the Global Era; Duke University Press: Durham, NC, USA, 2003.

2. Oswalt, P. Introduction. In Shrinking Cities. 2: Interventions; Oswalt, P., Ed.; Hatje Cantz: Ostfildern-Ruit, Germany, 2006; pp. 13-18.

3. Ward, D. The Guggenheim effect, cities reborn: The challenge of an urban renaissance. The Guardian, 30 October 2002.

4. Organisation for Economic Co-operation and Development (OECD). Culture and Local Development; LEED Programm: Trento, Italy, 2005.

5. Cerreta, M.; Daldanise, G.; Sposito, S. Culture-led regeneration for urban spaces monitoring complex values networks in action. Urbani Izziv 2018, 29, 9-28. [CrossRef]

6. Roberts, P.; Sykes, H. (Eds.) Urban. Regeneration: A Handbook; SAGE: London, UK, 2000.

7. Leary, M.E.; McCarthy, J. Introduction: Urban Regeneration, a global phenomenon. In The Routledge Companion to Urban Regeneration; Leary, M.E., McCarthy, J., Eds.; Routledge: London, UK, 2013; pp. 1-14.

8. Miles, S.; Paddison, R. Introduction: The Rise and Rise of Culture-led Urban Regeneration. Urban. Stud. 2005, 42, 833-839. [CrossRef]

9. Landry, C.; Bianchini, F. The Creative City; Demos: London, UK, 1995.

10. Landry, C. The Creative City. A Toolkit for Urban Innovators; Earthscan Publications: London, UK, 2000.

11. Ferilli, G.; Sacco, P.L.; Tavano Blessi, G.; Forbici, S. Power to the people: When culture works as a social catalyst in urban regeneration processes (and when it does not). Eur. Plan. Stud. 2016, 25, 242-258. [CrossRef]

12. Carta, M. Augmented City: A Paradigm Shift; LISt Lab.: Trento, Italy, 2017.

13. Lippi Bruni, M.; Rago, S.; Ugolini, C. Il Ruolo Delle Mutue Sanitarie Integrative. Le Società di Mutuo Soccorso Nella Costruzione del Nuovo Welfare di Comunità; Il Mulino: Bologna, Italy, 2012.

14. Rago, S.; Venturi, P.; Daconto, G. Innovazione Sociale e Governance Territoriale: La Dimensione Trasformativa delle Cooperative di Comunità; Fondazione Giacomo Brodolini: Roma, Italy, 2020.

15. Lysgård, H.K. Creativity, Culture and Urban Strategies: A Fallacy in Cultural Urban Strategies. Eur. Plan. Stud. 2012, 20, 1281-1300. [CrossRef]

16. Forte, F.; De Paola, P. How can Street Art have economic value? Sustainability 2019, 11, 580. [CrossRef]

17. Wilson, D.; Keil, R. The real creative class. Soc. Cult. Geogr. 2008, 9, 841-847. [CrossRef]

18. Zukin, S. Consuming authenticity: From outposts of difference to means of exclusion. Cult. Stud. 2008, 22, 724-748. [CrossRef]

19. Sacco, P.L. Culture 3.0: A New Perspective for the EU. 2014-2020 Structural Funds Programming; EENC Paper; European Commission: Brussels, Belgium, 2011.

20. Boltanski, L.; Esquerre, A. Enrichissement: Une critique de la Marchandise; Gallimard: Paris, France, 2017.

21. Oswalt, P. Shrinking Cities. 1: International Research; Hatje Cantz: Ostfildern-Ruit, Germany, 2005.

22. Oswalt, P.; Rieniets, T. (Eds.) Atlas of Shrinking Cities; Hatje Cantz: Ostfildern-Ruit, Germany, 2006.

23. Shrink Smart-The Governance of Shrinkage. 2012. Available online: https:/ / www.ufz.de/shrinksmart (accessed on 14 April 2021).

24. Lynch, K. Wasting Away; Southworth, M., Ed.; Sierra Club Books: San Francisco, CA, USA, 1990.

25. Giuffrida, S.; Trovato, M.R.; Strigari, A.; Napoli, G. "Houses for one euro" and the territory. Some estimation issues for the "geographic debt" reduction. Smart Innov. Syst. Technol. 2021, 178, 1043-1052.

26. Ciorra, P.; Marini, S. (Eds.) Recycle: Strategies for Architecture, City and Planet; MAXXI/Electa: Roma-Milano, Italy, 2012.

27. Diener, R.; Herzog, J.; Meili, M.; de Meuron, P.; Schmid, C. Die Schweiz-Ein Städtebauliches Portrait: Bd. 1: Einführung; Bd. 2: Grenzen, Gemeinden-Eine Kurze Geschichte des Ter-ritoriums; Bd. 3: Materialien; Institut Stadt der Gegenwart: Basel, Switzerland, 2005.

28. Del Molino, S. La España Vacía; Turner: Madrid, Spain, 2016.

29. Pallagst, K.; Aber, J.; Audirac, I.; Cunningham Sabot, E.C. The Future of Shrinking Cities-Problems, Patterns and Strategies of Urban. Transformation in a Global Context; Center for Global Metropolitan Studies, Institute of Urban and Regional Development and the Shrinking Cities International Research Network: Berkeley, CA, USA, 2009.

30. Nam, C.W.; Richardson, H.W. Shrinking Cities: A Global Perspective; Taylor \& Francis: London, UK, 2014.

31. McKinsey Global Institute. Urban. World: Meeting the Demographic Challenge; McKinsey \& Company: Chicago, IL, USA, 2016.

32. Dematteis, G. (Ed.) Montanari per Scelta. Indizi di Rinascita Nella Montagna Piemontese; Terre Alte-Dislivelli, Franco Angeli Editore: Milano, Italy, 2011.

33. Corrado, F.; Dematteis, G.; Di Gioia, A. (Eds.) Nuovi Montanari. Abitare le Alpi Nel XXI Secolo; Terre Alte-Dislivelli, Franco Angeli editore: Milano, Italy, 2014.

34. Ota, K. Islands and Villages. 2018. Available online: https://www.cca.qc.ca/en/issues/26/what-about-the-provinces/56455/ islands-and-villages (accessed on 20 October 2021).

35. Ota, K. The Posturban Phenomenon. 2018. Available online: https://www.cca.qc.ca/en/issues/26/what-about-the-provinces/ 56442 / the-posturban-phenomenon (accessed on 20 October 2021).

36. Daldanise, G.; Gravagnuolo, A.; Oppido, S.; Ragozino, S.; Cerreta, M.; Esposito De Vita, G. Economie circolari per il patrimonio culturale: Processi sinergici di riuso adattivo per la rigenerazione urbana. In Atti della XXI Conferenza Nazionale SIU "Confini, Movimenti, Luoghi. Politiche e Progetti per Città e Territori in Transizione. Firenze 6-8 Giugno 2018"; Planum: Milano, Italy, 2019. 
37. Romero Gonzalez, E.; Guadiana, L. Culture-led downtown regeneration or creative gentrification? In The Routledge Companion to Urban Regeneration; Leary, M.E., McCarthy, J., Eds.; Routledge: London, UK, 2013; pp. 536-547.

38. Bryson, J.R.; Andres, L.; Mulhall, R. People, place, space and city-regions: Towards an integrated or systemic approach to reading city-region regeneration economies. In A Research Agenda for Regeneration Economies. Reading City-Regions; Bryson, J.R., Andres, L., Mulhall, R., Eds.; Edward Elgar Publishing: Cheltenham, UK, 2018.

39. AMO; Koolhaas, R. Countryside, a Report: Countryside in Your Pocket! Taschen: Koeln, Germany, 2020.

40. Matsutani, A. Shrinking-Population Economics. Lessons from Japan; International House of Japan: Tokyo, Japan, 2006.

41. Zamagni, S.; Venturi, P.; Rago, S. Valutare l'impatto sociale. La questione della misurazione nelle imprese sociali. Impresa Sociale 2015, 6, 77-97.

42. Coppola, A.; Del Fabbro, M.; Lanzani, A.; Pessina, G.; Zanfi, F. (Eds.) Ricomporre i Divari. Politiche e Progetti Territoriali Contro le Disuguaglianze e per la Transizione Ecologica; Il Mulino: Bologna, Italy, 2020.

43. Carrosio, G.; Tantillo, F. Uscire dal Vecchio Mondo. Dialogo con Fabrizio Barca. 2017. Available online: https: / www.che-fare. com/uscire-dal-vecchio-mondo-dialogo-con-fabrizio-barca (accessed on 20 October 2021).

44. Sacco, P.L.; Ferilli, G.; Tavano Blessi, G. Understanding culture-led local development: A critique of alternative theoretical explanations. Urban. Stud. 2014, 51, 2806-2821. [CrossRef]

45. Rodríguez-Pose, A. The revenge of the places that don't matter (and what to do about it). Camb. J. Reg. Econ. Soc. 2018, 11, 189-209. [CrossRef]

46. Hollander, J.B. A Research Agenda for Shrinking Cities; Edward Elgar Publishing: Cheltenham, UK, 2018.

47. Zinganel, M. Tourism in a luxury of void. The production of desire, cultural transfer, and unintentional side effects. In Shrinking Cities. 2: Interventions; Oswalt, P., Ed.; Hatje Cantz: Ostfildern-Ruit, Germany, 2006; pp. 244-249.

48. Marzona, A. Art Park Verzegnis; Andrea Moro Editore: Tolmezzo, Italy, 2006.

49. Müller, L.; Miki, A. (Eds.) Insular Insight; Lars Müller Publishers: Zurich, Switzerland, 2011.

50. Sejima, K. Inujima "Art House Project"; Millegraph: Tokyo, Japan, 2014.

51. Judd, D. In defense of my work. 1977. In Chinati: The Vision of Donald Judd; Stockebrand, M., Ed.; Chinati Foundation with Yale University Press: New Haven, CT, USA, 2010; pp. 276-277.

52. Stockebrand, M. The Journey to Marfa and the Pathways to Chinati. In Chinati: The Vision of Donald Judd; Stockebrand, M., Ed.; Chinati Foundation with Yale University Press: New Haven, CT, USA, 2010.

53. Soja, E.W. Seeking Spatial Justice; University of Minnesota Press: Minneapolis, MN, USA, 2010.

54. Sacco, P.L.; Crociata, A. A Conceptual Regulatory Framework for the Design and Evaluation of Complex, Participative Cultural Planning Strategies. Int. J. Urban. Reg. Res. 2013, 37, 1688-1706. [CrossRef]

55. Cerreta, M.; Panaro, S. Deliberative spatial multi-criteria evaluation (DSM-CE): Forming shared cultural values. In Lecture Notes in Computer Science (Including Subseries Lecture Notes in Artificial Intelligence and Lecture Notes in Bioinformatics; Springer: Berlin/Heidelberg, Germany, 2017; Volume 10406, pp. 77-90. [CrossRef]

56. Von Mayr, G. Die Gesetzmäßigkeit im Gesellschaftsleben; Oldenbourg: Munich, Germany, 1877. Available online: https:/ /archive. org/details / diegesetzmssig00mayruoft/page/78/mode/2up?ref=ol\&view=theater (accessed on 20 October 2021).

57. Cerreta, M.; Giovene Di Girasole, E. Towards heritage community assessment: Indicators proposal for the self-evaluation in Faro convention network process. Sustainability 2020, 12, 9862. [CrossRef]

58. Bailey, N. The role, organisation and contribution of community enterprise to urban regeneration policy in the UK. Prog. Plan. 2012, 77, 1-35. [CrossRef]

59. Hinves, J. Becoming a Cultural Entrepeneur: Creative Industries, Culture-led Regeneration and Identity. In Cultural Policy, Work and Identity: The Creation, Renewal and Negotiation of Professional Subjectivities; Paquette, J., Ed.; Routlegde: London, UK, 2012; pp. 161-177.

60. Mangialardo, A.; Micelli, E. The Role of the Social Entrepreneur in Bottom-up Enhancement of Italian Public Real-Estate Properties. In Integrated Evaluation for the Management of Contemporary Cities. SIEV 2016. Green Energy and Technology; Mondini, G., Fattinnanzi, E., Oppio, A., Bottero, M., Stanghellini, S., Eds.; Springer: Cham, Switzerland, 2018. [CrossRef]

61. Carlini, E.; Valle, P. (Eds.) Visione Continua. Musei All'aperto: Inserimento Urbanistico e Territoriale_Egidio Marzona e Villa di Verzegnis; GFP Editore: Azzano Decimo, Italy, 1999.

62. European Commission. The Economy of Culture in Europe; Study prepared by KEA European Affairs: Brussels, Belgium, 2006.

63. European Commission. Regulation (EU) 2021/1058 of the European Parliament and of the Council of 24 June 2021 on the European Regional Development Fund and on the Cohesion Fund. 2021. Available online: http:/ /data.europa.eu/eli/reg/2021/1058/oj (accessed on 20 October 2021).

64. Boltanski, L.; Chiapello, È. Le Nouvel Esprit du Capitalism; Gallimard: Paris, France, 1999.

65. Mangialardo, A.; Micelli, E. Grass-roots participation to enhance public real estate properties. Just a fad? Land Use Policy 2021, 103, 105290. [CrossRef]

66. Micelli, E. Enabling real property. How public real estate assets can serve urban regeneration. Territorio 2018, 87, 93-97.

67. Texas Tribune. Coronavirus is Ablaze in West Texas as Tourists Flock to Big Bend and Marfa. Hospitals Are Running Out of Overflow Options. 2020. Available online: https://www.click2houston.com/news/texas/2020/12/02/coronavirus-is-ablaze-inwest-texas-as-tourists-flock-to-big-bend-and-marfa-hospitals-are-running-out-of-overflow-options (accessed on 20 October 2021). 
68. Reynaud-Dewar, L. Beyond the Land of Minimal Possessions; HD Film, Color, Stereo, 82'; Courtesy of the Artist and Galerie Emanuel Layr: Vienna, Austria, 2018.

69. Bartoli, A. A platform for change. Farm e Favara. Passato, presente e futuro. In Arcipelago Italia: Progetti per il Futuro dei Territori Interni del Paese: Padiglione Italia Alla Biennale Architettura 2018; Cucinella, M., Ed.; Quodlibet: Macerata, Italy, 2018 ; pp. 148-149.

70. Caramaschi, S. Design Actions for the Global Gaze. Evolution and Contradictions of Temporary Installations in San Francisco's Public Space. Plan. Theory Pract. 2020, 21, 748-766. [CrossRef]

71. Oppio, A.; Bottero, M.; Dell'Anna, F.; Dell'Ovo, M.; Gabrielli, L. Evaluating the Urban Quality through a Hybrid Approach: Application in the Milan (Italy) City Area. In Lecture Notes in Computer Science (Including Subseries Lecture Notes in Artificial Intelligence and Lecture Notes in Bioinformatics; Springer: Berlin/Heidelberg, Germany, 2020; Volume 12253, pp. 300-315. 